\title{
POSSIBILITIES OF USING A “PR STUNT" IN STRATEGIC COMMUNICATION OF HIGHER EDUCATION
}

\author{
Lucijano Jakšić, PhD, lecturer \\ European Business School Zagreb \\ 119 Selska cesta, Zagreb, Croatia \\ e-mail: Iucijano.jaksic@ebus.hr \\ Krešimir Dabo, PhD, senior lecturer \\ Edward Bernays University College \\ 8 Ratkajev prolaz, Zagreb, Croatia \\ e-mail: kresimir.dabo@bernays.hr \\ Marija Volarević, MA Journalism, lecturer \\ European Business School Zagreb \\ 119 Selska cesta, Zagreb, Croatia \\ e-mail: marija.volarevic@ebus.hr
}

\begin{abstract}
"PR stunt" or "Publicity Stunt" is a carefully planned event with the aim of drawing public attention to the organizers of the stunt or to another goal of the stunt organization. The reasons for considering the use of a promotional stunt have a great potential for a return to investment and the "earnings" from unpaid advertisements in the media which spontaneously reported that something interesting had happened. Apart from the media themselves, the general public also significantly contributes to the spread of publicity through stunts, so that today practically everyone can record the interesting thing they come across via their smartphone and share it on the Internet. Higher education, but also general education, has transformed from a traditional centuries-old approach where the focus was on teachers and institutions to a modern mass approach where the focus is on students and studying occurs through partnership and cooperation within the learning process. The emergence of mass higher education in almost all countries of the world now implies public criticism of factors such as: the quality of lifelong learning services, the success of examinations, the management of the institution, the form of funding and the student standard. Massification is accompanied by the expansion and diversification of higher education, and the result of the latter is the emergence of competition among individual higher education institutions. Therefore, the importance of effectively conveying the message of a higher education institution to a (potential) student or his sponsor of education therefore becomes the subject of professional marketing communication. The paper provides an
\end{abstract}


overview of PR Stunts in Croatia and the world and proposes thematic guidelines for their organization.

Keywords: Public relations, PR stunt, strategic communication, higher education, marketing

\section{INTRODUCTION}

A "PR stunt" or a "publicity stunt" is a carefully planned event aiming to draw public attention to the organizers of the stunt or another objective of the stunt. The reasons for considering the use of a promotional stunt in public are the great potential for a return on investment and the "earnings" from unpaid advertisements in the media that spontaneously report that something interesting has happened. In addition to the media, the population exposed to PR stunts also contributes significantly to the spread of publicity through stunts, so that today practically everyone can instantly record the curiosity they come across via their mobile device and share it on the Internet (Sugget, 2019).

According to Edward Bernays, a pioneer of public relations, the appearance of public relations goes back to the very beginning of human history, that is, to the relations between leaders and their followers. Power, authority, and social control have existed much longer than the earliest historical records, and the three elements of public relations are as old as human society: informing, persuading and integrating people (Bernays, 1952, p. 3). It is to be assumed that the first primitive human societies were successful in controlling the community through force, threats, persuasion and magical and perceived supernatural rituals. With the emergence of despotisms like Sumer, Babylon, Assyria, Persia, Egypt and others, building the reputation and importance of rulers was marked by ingenuity and surprisingly high costs for the formation of public opinion, before it was maintained by a large population. Written and artistic sources from that time speak of the heroism of the rulers in battles and campaigns and the conquest of the vastness of the then-known and unknown world. The personality and political publicity of the rulers back then is evident even after five thousand years. The importance of individualism and the opinion of the non-ruler comes to the fore with the emergence of Hellenic civilization, democratic society and the flourishing of trade due to the advent of coinage (Bernays, 1952, p. 3).

Here it is possible to assume that the oratory skills of the political speakers such as Pericles and Demosthenes, due to their effectiveness and method, could represent a proto form of a propaganda stunt. From then until today, according to Aristotle's "Rhetoric", new ideas, a planned speech structure, ways of expression, methods of argumentation and a memory of a speech are needed for the successful transmission of a message (in speaking) (Hornblower and Spawforth, 2014, p. 660). According to Horton (2016), promotional acrobatics very often fail to convey a message and he finds the cause in unsuccessfully realized semiotics, i.e., in a sign process or activity intending to create a meaningful message. The English word "stunt" comes from the Middle English form ( $11^{\text {th }}-15^{\text {th }}$ century) and the word "stunt", which means foolish, small-minded or short and comes from the old Nordic word "stuttr" for short or dwarf. Since 1878, the word "stunt" has had the meaning of "an unusual and difficult undertaking that requires great skill or courage, especially to attract 
attention or publicity." The challenge for any promotional stunt is to visually preserve the desired message in front of the public as a witness and this is not easy.

\section{TRANSFORMATION OF HIGHER EDUCATION}

Higher education, but also education in the world generally, has been transformed from a traditional, centuries-old approach where the focus was on teachers and institutions to a modern mass approach where the focus is on students and study takes place through partnership and cooperation within the learning process. The emergence of mass higher education in almost all countries of the world now implies public criticism of factors such as quality of lifelong learning service, examination performance, institution management, the form of funding and student standard (Maringe and Gibbs, 2008, p. 30). Massification is accompanied by the expansion and diversification of higher education, and the result of the latter is the emergence of competition between individual higher education institutions. The importance of effectively conveying the message of a higher education institution to a (potential) student or his or her education sponsor, therefore, becomes the subject of professional marketing communication. It remains to be discussed whether students should consequently be equated with the "customer" category and lecturers with the "service provider" category. Students pay for their education but still do not have the same rights and privileges as customers in the classic buying process. Although they have paid for tuition, after failing an exam they are not refunded, they cannot return the defective product (education) to the store in case they are not satisfied with the product or service of the higher education institution. Those who graduate receive a product in the intangible form of a vocation found in their minds, or more precisely, a skill with a limited scope in human society (Maringe and Gibbs, 2008, pp. 30-33).

Higher education has another interesting feature, the "positional good" described by Fred Hirsch (1976). The positional good in higher education is that the successful completion of education at some institutions brings with it better social status, greater opportunities for professional development and more business opportunities in the eyes of students, parents and employers. To justify the positional good of eight prestigious American universities, the so-called Ivy League Universities, the still contradictory results of research confirming and disputing the high opportunity benefits or low return on high investment have been discussed for many years (Eide and Showalter, 1998, Berg Dale and Krueger, 1999, Geoffrey, 2018, Parker, 2019). Reasons to discuss the value of studying at the eight Ivy League Universities lie in the importance of numerical indicators. For example, in 2018 , there were 63,873 undergraduate students, 75,586 postgraduate students, \$134.54 billion earned from tuition, 22,797 teaching staff and 160 Nobel laureates from just Harvard University. Given that no institution can excel in all segments of its business or meet the needs of all groups of users, a newly established higher education institution must determine the specific aspects around which it will position itself in the market (Maringe and Gibbs, p. 60, 2008). Positioning involves the process of creating an image and related perceptions of value for users from a target group. The target group must be able to understand what the image of a higher education brand represents compared to its competition (Wilson and Gilligan, p.354, 2005). Therefore, the obvious task of a marketing strategist is to ensure the prominence of a brand in the best way and its long-term 
successful sales. To this end, a brand or product must be successfully maneuvered to go through all the stages of the selection process, from "total available offer" to "conscious offer", then to the shortlist "that comes into consideration" and finally to the "shortlist" or the level at which a customer/sponsor makes the final purchase decision. Regardless of the numerous research that points out rational arguments when making a final purchase decision, it is mostly a potentially more complex behavior that precedes the final decision. A marketing strategist must have a clear understanding of the criteria by which his target group compares different bidders in order to be able to elevate the qualities of his brand among a multitude of other bidders through targeted activities (Wilson and Gilligan, p.185, 2005). For these reasons, market communication is increasingly being transformed from a form of intervention to a new proactive communication practice with the ultimate goal of building relationships between an organization and its public. Such an "audience-centered" communication is not so much about fixing difficulties and overcoming challenges as it is about fostering dialogue with stakeholders where the ultimate goal is the image and reputation of an organization. For this dialogue to be successful, communication must be based on behavior, needs and the style of information preferred by the target group (Fill, 2010, p. 17). The communication mix used in all interactions must be consistent with organizational goals and strategies and the content of the communication and the agreed protocol must be relevant, likable, time-accurate and content-valuable (Fill, 2010, p. 256).

\section{STRATEGIC COMMUNICATION}

Many organizations neither develop nor implement a communication strategy. To some extent, the development of a brand strategy, advertising strategy and some forms of integrated marketing communication is encountered in practice. There are very few examples of a guided communication strategy at the corporate level or examples where the strategist (communicator) practitioner manages to achieve a qualitative impact on the formulation of the strategy at the highest level of corporate governance (Steyn, 2003). A strategic approach to communication implies an integrated approach at several levels where each communication function meets specific goals, is focused on the priorities that are planned to achieve the goals and includes the selection of the most effective communication channels. In order to achieve full strategic impact, all realized communication and all communication channels must be adjusted to the achievement of the goal and consistent both with each other and with the corporate strategy (Argenti, Howell, Beck, 2005). 
Table 1. Strategic approach to communication

\begin{tabular}{|c|c|c|c|c|}
\hline \multirow{2}{*}{$\begin{array}{l}\text { COMMUNICATIVE } \\
\text { FUNCTIONS }\end{array}$} & \multirow{2}{*}{ OBJECTIVES } & \multicolumn{2}{|c|}{ CONSTITUENCIES } & \multirow{2}{*}{ CHANNELS } \\
\hline & & Primary & Secondary & \\
\hline Media relations (1) & $\begin{array}{l}\text { Public relations } \\
(4), \\
\text { Crisis } \\
\text { management }\end{array}$ & $\begin{array}{l}\text { All constituencies } \\
\text { (8) }\end{array}$ & Media & $\begin{array}{l}\text { Press releases, } \\
\text { interviews }\end{array}$ \\
\hline $\begin{array}{l}\text { Employee } \\
\text { communications }\end{array}$ & $\begin{array}{l}\text { Internal } \\
\text { consensus } \\
\text { building }\end{array}$ & Employees & $\begin{array}{l}\text { Customers, } \\
\text { families }\end{array}$ & $\begin{array}{l}\text { Town hall } \\
\text { meetings, } \\
\text { memos, } \\
\text { newsletters } \\
\end{array}$ \\
\hline $\begin{array}{l}\text { Financial } \\
\text { communications }\end{array}$ & $\begin{array}{l}\text { Transparency, } \\
\text { meeting financial } \\
\text { expectations (5) }\end{array}$ & Investors & Analysts, media & $\begin{array}{l}\text { Conference calls, } \\
\text { CEO/CFO }\end{array}$ \\
\hline $\begin{array}{l}\text { Community } \\
\text { relations ( } 2 \text { ) }\end{array}$ & $\begin{array}{l}\text { Image building } \\
(6)\end{array}$ & Communities & NGOs, media & $\begin{array}{l}\text { Events, speeches, } \\
\text { philanthropy }\end{array}$ \\
\hline $\begin{array}{l}\text { Government } \\
\text { relations }\end{array}$ & $\begin{array}{l}\text { Regulatory } \\
\text { compliance, } \\
\text { meeting social } \\
\text { expectations }\end{array}$ & Regulators & Media, customers & $\begin{array}{l}\text { Lobbying efforts, } \\
\text { one-on-one } \\
\text { meetings }\end{array}$ \\
\hline $\begin{array}{l}\text { Marketing } \\
\text { communications (3) }\end{array}$ & $\begin{array}{l}\text { Driving sales (7), } \\
\text { building image }\end{array}$ & Customers & $\begin{array}{l}\text { All key } \\
\text { constituencies }\end{array}$ & $\begin{array}{l}\text { Advertising, } \\
\text { promotions }\end{array}$ \\
\hline
\end{tabular}

Source: Argenti, Howell, Beck, 2005

Public relations and thus promotional stunts are largely intertwined with strategic communication. Both aim to grow an organization through successful communication and require strong oral and written communication, interpersonal skills and work in multidisciplinary teams (Maryville University, n.d.). Theoretically, the importance of a promotional stunt can be identified within almost all elements of a strategic approach to communication and as suggested and numerated in bold in Table 1. If a promotional stunt in practice achieves or exceeds the planned publicity, it can gain future pertinence in strategic communication. Following the above, the linkage of a promotional stunt with each (in the table) bold element of a strategic approach to communication will be clarified.

1. Media relations: according to Graham (2016), public relations agencies establish a symbiosis with newsroom/TV editorial offices, as PR people regularly obtain (usually true) news that also benefits their clients. Many news publishers are able to publish a word-for-word statement if the news is prepared with an effort to look like a classic newspaper article. Therefore, even in the case of good/built liaisons with the media, the news about a promotional stunt can be published as a sensation and completely accurately published news (without missed or wrong information/interpretation).

2. Community relations: local initiatives can have a significant effect on improving a company's image with the public who are potential customers, but these benefits are often overlooked. For this reason, PR people resort to taking such initiatives, which may have the characteristics of a promotional stunt (PRMR, n.d.). 
3. Marketing communication: according to Tomša and Snoj (2014), marketing communication is one of the elements of the communication mix and it is necessary to distinguish between tools for marketing communication (advertising, personal sales, promotional sales, public relations and direct marketing and according to Shimp, 2003, p.4, Semenik 2002, pp. 261, Pickton and Broderick 2001, pp. 454-613, also sponsorships, point of sale communication, online advertising, trading, point of sale, product packaging, exhibitions, fairs) from marketing communication channels (includes anything that can convey a marketing message according to Pickton and Broderick 2001, p. 199). Among other things, the literature defines marketing communication as a process of communication in marketing with the purpose of creating demand for a brand, product, service or person.

4. Public relations: as an important goal of a strategic approach to communication, they must result in creating, maintaining and protecting the reputation of the organization, strengthening its prestige and reflecting the desired image of the organization. Since a promotional stunt, depending on the intensity of its positive or negative impact but also a possible failure in the idea and/or performance, can have a very significant positive or negative effect on the reputation of an organization (Reference for Business, n.d.). Therefore, the implementation of a promotional stunt carries certain risks that need to be identified and managed in parallel with the development of a stunt project.

5. Fulfillment of financial expectations for the financial reporting function: it should primarily be viewed from the aspect of invested/obtained. Effective press releases through a promotional stunt can represent a cost-effective choice or significant savings for all sizes of companies if a successfully implemented stunt gains the attention of, for example, independent reporters (Media Update, 2019). On the other hand, paid advertising that can be very accurately displayed and tracked as an expense in financial statements is not always successful (lack of expected effects on sales growth) because some target groups do not trust ads. It is to be assumed that some interesting news works more convincingly, by published by a reputable newspaper house (Media Update, 2019).

6. Image building: it takes place in several phases and on several levels with the aim of emphasizing uniqueness over the competition. If the image of an organization improves by focusing on the development of elements such as the value system of the organization, mission, goals and methods of communication, the desired message of a promotional stunt must be consistent with all these elements in building the image (Tymowicz, n.d.).

7. Sales management: it aims to make the best use of significant funds (usually $5-15 \%$ of total revenue) for further sales growth. Sales excellence depends on five elements: 1. identifying the right chances with a view of what the market will look like in a year or later, 2. allocating sales resources based on individual sales performance indicators, 3. ultimate excellence in the execution of the sales message (perfect customer pitch) for the product/service according to customer segmentation, 4. consistency in the approach to sales, 5 . building a correct operational model that includes all of the above (Chappuis, n.d.). Consequently, the promotional stunt in its design and execution must be in the function of sales growth. 
8. Target groups: they are strategically defined customer groups that we reasonably assume are interested in a product or service. The presumption of their existence is the basis for starting any business. If potential customers are not segmented according to some specifics, a sales plan which would aim at further sales growth cannot be performed, and therefore such a plan is characterized by a general set of in the same way performed marketing activities (Koldyshev, 2020). A promotional stunt can therefore be a very sophisticated tool for conveying a message to our target audience.

\section{SELECTION CRITERIA FOR PROMOTIONAL ASSIGNMENTS}

It should be noted that the question remains which events in practice can be characterized as promotional stunts (in higher education) and according to which characteristics can we qualify them as such? Based on the theoretical background and review of available stunts, the following criteria were selected:

1. A planned event designed to draw public attention to the organizers or the topic (higher education),

2. The event aims to attract public attention and raise awareness about a concept, product or service,

3. The event is organized by professionals or amateurs,

4. The event has the characteristics of news worth publishing,

5. The event is unusual, exceptional, demanding in performance, requires courage, is skillfully performed,

6. By initiating and managing the event, the organizer retains to a greater or lesser extent control over the content of media announcements (recordings, press conferences, etc.) (Sugget, 2019).

Surprisingly, any promotional stunt shares all the mentioned criteria with the description of the characteristics of "conceptual art" and it overlaps, in its nature, with "artistic installation" and "artistic performance". Conceptual art, in general, has no essential financial value, and by successfully performing it, the artist primarily aims to send strong socio-political comments or messages (Collins, 2008a). On the other hand, promotional wit is not limited in the imagination of expression and can take on the characteristics of the target level of artistic performance (art, visual, plastic, decorative, applied and performing (Collins, 2008b)) in order to achieve the best possible investment (for a higher education organization).

\section{TYPES OF PROMOTIONAL STUNTS IN HIGHER EDUCATION}

According to the well-known New York public relations agency "5W" (5WPR), there are three main categories of PR stunts that determine the success of an activity. These are community involvement, memorability and uniqueness. Blair Dawson further explains the characteristics of a successful PR stunt (Blaire Dowson, 2020): 1. crowded marketplace and looking to stand out, 2. targeting a new audience, 3. company is a newer name in the market, 4 . your niche is trendy, 5 . your category does not get substantial organic press, 6 . 
you are looking to grow your social presence. Similarly, Rich Leigh (Radioactive PR, 2018) confirms the four key elements of a good PR stunt: 1 . the stunt should be easily explainable in a sentence, 2 . it should relate to the product/service it is aiming to promote, 3 . it should have clear objectives, 4 . it should be visual.

Human creativity allows for an infinite number of variations on a theme, and we can assume that it is not limited to the stunts described here. The paper will describe which types of promotional stunts in higher education were found in the data sources available for this research. The following phenomena are listed and described, which are a kind of thematic representatives of the category, which at the same time does not mean that they are the only or best examples but are used for this primary review:

1. A flash mob (Flash Mob Geek, 2019) is organized in a common space during the time of the highest frequency of students during the lunch break in the canteen. The recording of the event in this example takes less than 6 minutes. Introductory shots (targeted) show how to register and enter the canteen (possible message - level of student safety), staff in the canteen (responsible approach in the organization of joint services), sound and displays of many people of different skin color in the canteen (availability, popularity of the institution, diversity, socialization), display of self-service plates full of food and present staff in protective work clothes (quality and variety of food, food safety). The stunt begins with a student getting up from the crowd and singing. The students present (spectators) react with initial surprise and enthusiasm because of the obvious quality of the performance, the choice of the song (Queen Somebody to Love) and the symbolism of the verses in the song (the weight of everyday life, believing in a positive outcome and love). Cameras monitor the reactions of the students from different angles. The choir gathers in the center of the canteen, there are drums and a choreography where scattered performers invite students to join them in singing. The stunt ends with a display of enthusiasm and a standing ovation. The last shots show the atmosphere going back to normal and details about the organizer of the stunt. The primary skill or skills the stunt requires: a mixed rehearsed choir/group of students with adequate vocal or other (Dubrovnik Summer Festival, 2013) capacities that can successfully perform a directed performance and choreography. Other: cameramen, sound system, editing. The minimum required level of organization, performance and production (amateur and/or professional): it is possible to organize the stunt at an amateur level with sufficient engagement of the necessary resources and quality production. The message for the population exposed to the stunt: the institution is trendy, the quality of studying in Brazil, Brazil is a country that accepts diversity, the creativity of Brazilian higher education institutions. The message for the target group: high quality of all aspects of studying at this institution, student safety at this institution, quality society, acceptance of diversity, many opportunities to learn. Event and content management: content is available on YouTube as well as on more popular websites and services if a keyword search is launched on the Google search engine. The content is also among the 20 (best) flash mob ideas on Pinterest.

2. A group of students participating in a charity running event (Kučić, 2017, Adria More, 2019) on the example of "Wings for Life World Run", an international project without borders and limits in the number of participants. Participant engagement is channeled 
one hundred percent into funding research into the treatment of spinal cord injuries. In 2017, the race was held in Zadar, Croatia, for the 4th year in a row, and a team of 396 students from the University of Rijeka broke the world record by being the largest student team participating in the race, which provided added value of news worth publishing. The primary skill or skills the stunt requires: organizational skills, entertaining participants. Other: cameramen, journalists. The minimum required level of organization, performance and production (amateur and/or professional): the organization of the team or race can be carried out by students with or without mentoring. The race can be organized in the city of Zadar, one of the twelve so-called "Flagship Run" locations (organized races) or the participants can take part regardless of location, using a mobile application and geolocator on their smartphones. The message for the population exposed to the stunt: maximum support for those who cannot run, victory over their own physical limitations. The message for the target group: common goal, acceptance of diversity, socializing, support, together it is easier. Event and content management: visual and audio recordings of the participating teams or individual portraits of various participants and their motives for participating in the race can be used for promotional purposes of the university because there are no minimum physical predispositions for participants and press releases.

3. A student rowing race (Noble, 2020) between competing colleges on the example of the famous "Boat Race" between the University of Oxford and the University of Cambridge, a tradition since 1829 (The Boat Race Company Ltd., n.d.). The race takes place on a 6.8-kilometer stretch on the River Thames (from Putney Bridge to Mortlake Point) and is broadcast by state television with an estimated rating of 15 million viewers (Clayton Hotel, 2020). Famous actors, historians and Olympic winners are among the most notable participants in the race in its long history. (BBC, n.d.). The primary skill or skills the stunt requires: physical fitness, an interdisciplinary organizational team. Other: high organizational requirements. The minimum required level of organization, performance and production (amateur and/or professional): if this type of race is organized on demanding waters, in addition to the organizing team/teams, it must involve several types of (public) services (health, rescue), media, police, catering and more. The message for the population exposed to the stunt: the rivalry of the best universities in the UK in an extremely strenuous form of sport (Georgeson, 2018), encouraging harmonious intellectual and physical development of young people, connecting the winning image of the team with the image of the city the team comes from. The message for the target group: the opportunity to go down in history within 17 minutes of the race (The Boat Race Company Ltd., n.d.), the best in science and the best in sports. Event and content management: the project may include live streaming, interviews with team members and coaches, press releases and conferences, recordings, photos.

4. Exhibition of works by students of the Academy of Fine Arts. This example is the "final exhibition of the best student works" and a result of the teaching process of the Academy of Fine Arts, University of Zagreb (Tportal, 2020). The primary skill or skills the stunt requires: a selection of student papers that will best present the results of the teaching process. Other: it is necessary to provide adequate space for exhibiting works and time to visit exhibitions. The minimum required level of organization, performance and production (amateur and/or professional): it is understood that 
works that are the result of the selection process of a panel of professors/artists will be selected for the exhibition and that the exhibited works are the best representatives of art and the skills of the artist-creator (Britannica, 2020). The message for the population exposed to the stunt: the importance of the Academy for the cultural life of the city and the state, arousing interest in art and artistic creation, the importance of the Academy in the world. The message for the target group: works from the fields of painting, graphics, sculpture, teaching, animated film and new media, conservation and restoration of works of art (Tportal, 2020) were presented, aiming to arouse the interests of potential students with artistic inclinations and the possibility of attracting potential sponsors to purchase works or fund scholarships for the most talented students as part of a socially responsible business (Erste Bank, n.d.). Event and content management: This stunt has the characteristics of an exhibition as a project and should be approached in this way. With each annual iteration, it is possible to introduce novelties such as prize games for the fastest visitors to the exhibition (Tportal, 2020) and more.

5. A concert or performance (Paun, 2013) of different ensembles of students (music, drama academies or other) as a "gift concert" with free tickets during which the results of the higher education teaching process are demonstrated. The primary skill or skills the stunt requires: selected students will perform and present the results of the teaching process in the best way. However, it should not be overlooked that playing a musical instrument, singing an opera and conducting are by nature "artistic musical performance", so the promotional stunt in the case of musical and vocal performance should be a certain detachment from "normal". The best example of such performance potential is the "2Cellos" project, which until 2019 (Guja, 2019) consisted of two former cello students of the Zagreb Academy of Music (Biography, 2017). Other: concert venue, concert date, live broadcast and more. The minimum required level of organization, performance and production (amateur and/or professional): The event must be organized and performed according to the rules of the profession and professional organization of a public event, concert or play (Volarić, 2016). The message for the population exposed to the stunt: the contribution of the institution to the public life and culture of the city and the international reputation of the state and the importance of higher education for new generations which thus influence the development of culture and art of human society. The message for the target group: as in this example, a stunt can be organized on a very large scale (more than 300 concerts, productions and events, (Music Academy in Zagreb, n.d.)) which can emphasize the size of the scope of studies and individual interests. Event and content management: concert organization management, live broadcast, recordings, photos, press releases.

6. A demonstration of the application of scientific methods in practice (IRT, 2019), including the example of the presentation of engineering failures or shortcomings in technical products (Kurelac, 2020). The primary skill or skills the stunt requires: specific technical knowledge and practical performance with proof. Other: an experiment proving a defect or omission needs to be adequately recorded with a camera and edited into quality video material for publication on public services such as YouTube. The minimum required level of organization, performance and production (amateur and/or professional): the demonstration must contain sufficient information about 
the settings of the experiment (Online Etymology Dictionary, n.d.) in order to verify the veracity of the results obtained. The message for the population exposed to the stunt: a higher education institution is trendy, the contribution of a higher education institution to science and profession, a modern approach to teaching. The message for the target group: a place of study with a modern and fun approach, where science merges with the needs of industry and modern business. Event and content management: a mentored group of students conducts and records an experiment according to a script, a live broadcast can be organized, press releases and additional press releases can be distributed as an evoked reaction (response) from the producer whose product was the subject of the experiment (CBG, 2020).

\section{CONCLUSION}

A promotional stunt plays an important role in strategic communication, mostly with its potential to attract attention and convey a message to target groups in a very unusual and very cost-effective way. Higher education has become widespread and has been transformed. The (potential) student is in focus more than ever in human history. Higher education is also characterized by the construct "positional good", so some world universities, such as members of the American "Ivy League", are perceived as more valuable by the professional public and the population exposed to stunts, and their degrees bring greater recognition in society and professional career than competitors'. Stunts, sketches, videos recorded with amateur equipment (primarily mobile devices) have become part of our everyday lives. Virtually anyone can record and post a video in a very short time on public services on the Internet and that video can become viral, with millions of views within a few days. This potential also applies to a promotional stunt in higher education. A promotional stunt finds its application and position in the functions, goals and target groups of strategic communication. The paper provides an overview of 6 types of promotional stunts related to the communication of higher education institutions as representatives of certain categories. Promotional stunts in higher education are not limited to these 6 types, but it is assumed that over time different types of human activities will be added. Furthermore, following the presented examples, it is clear that, with a dose of creativity, the desired publicity can be created and generated. Although the examples in this paper are not necessarily extraordinary, they can certainly be seen as attempts to create media visibility. That is why PR stunts can be a great tool for creating a better media positioning of higher education. However, it is necessary to design them more carefully and also strategically present them to the public, which demands better and more precise planning, content design and reflection on the effect of stunts. From all the above in this paper, we can conclude that a PR stunt as a special technique in public relations can achieve very concrete results for colleges, polytechnics and other higher education institutions. Very interesting and useful possibilities in creating PR stunts are reflected in various forms of creating publicity through, for example: 1 . organizing smaller events in open and crowded spaces that can attract attention, 2. creating events outside the usual scope of higher education institutions such as art exhibitions, sports competitions, 3. interventions in space through guerilla marketing with the aim of conveying the message and strengthening the visibility of the institution. This research is the basis for further research into the potential of the application of promotional stunts in higher education. 


\title{
POZICIONIRANJE „PR STUNT-A“ U STRATEŠKOM KOMUNICIRANJU VISOKOG ŠKOLSTVA
}

\author{
dr. sc. Lucijano Jakšić, predavač \\ Europska poslovna škola Zagreb \\ 119 Selska cesta, Zagreb, Hrvatska \\ e-mail: lucijano.jaksic@ebus.hr \\ dr. sc. Krešimir Dabo, viši predavač \\ Edward Bernays University College Zagreb \\ Ratkajev prolaz 8, 10000 Zagreb, Hrvatska \\ e-mail: kresimir.dabo@bernays.hr \\ Marija Volarević, mag. nov., predavač \\ Europska poslovna škola Zagreb \\ 119 Selska cesta, Zagreb, Hrvatska \\ e-mail: marija.volarevic@ebus.hr
}

\section{SAŽETAK}

„PR stunt“ ili PR akrobacija, odnosno promidžbena dosjetka je pomno planirani događaj s ciljem privlačenja pažnje javnosti na organizatore dosjetke ili na drugi cilj organizacije dosjetke. Razlozi za razmatranje upotrebe promidžbene dosjetke nalaze su u velikom potencijalu povrata na ulog te „zaradi“ od neplaćenih reklama u medijima koji su spontano izvijestili o tome da se nešto zanimljivo dogodilo. Osim samih medija, širenju publiciteta putem dosjetke značajno doprinosi i opća javnost na način da danas praktički svatko može putem svojeg smartfona trenutno zabilježiti zanimljivost na koju naiđe te ju podijeliti na internetu. Visoko školstvo, ali i školstvo u svijetu općenito, transformiralo se iz tradicionalnog višestoljetnog pristupa kada je u fokusu bio poučavatelj i institucija na suvremeni masovni pristup gdje je u fokusu student i studiranje se odvija kroz partnerstvo i suradnju unutar procesa učenja. Pojava masovnog visokog obrazovanja u skoro svim državama svijeta sada podrazumijeva javnu kritiku faktora poput: kvalitete usluge cjeloživotnog učenja, uspješnosti ispitivanja, upravljanja institucijom, oblika financiranja te studentskog standarda. Omasovljenje prati širenje i diverzifikacija visokog školstva, a rezultat potonjeg je pojava konkurencije između pojedinih visokoškolskih institucija. Važnost efektivnog prijenosa poruke visoko obrazovne institucije ka (potencijanom) studentu ili njegovom sponzoru školovanja stoga postaje predmet profesionalnog marketinškog komuniciranja. $U$ radu se daje pregled PR Stunt-ova u Hrvatskoj i svijetu te predlažu tematske smjernice pri organizaciji istih.

Ključne riječi: Odnosi s javnošću; PR stunt; strateška komunikacija; visoko obrazovanje; marketing 


\section{REFERENCES}

1. Adria More (2019). Wings for Life World Run opet u Zadru! Retrieved from: https://adria-more. $\mathrm{hr} / \mathrm{blog} /$ wings-for-life-world-run-opet-u-zadru/10.html (26.11.2020)

2. Argenti, P., A., Howell, R., A., Beck, K., A. (2005). The Strategic Communication Imperative. Massachusetts Institute of Technology, MIT Sloan Management Review (SMR), 46(3), pp.83-89.

3. BBC, (n.d.). The Things You Never Knew About the Boat Race. Retrieved from: https://www.bbc. co.uk/bitesize/articles/zhdm47h (1.12.2020)

4. Bernays, E., L. (1952). Public Relations. University of Oklahoma Press Norman. Retrieved from: https://books.google.hr/books?id=0NpSb5nmn5sC\&printsec=frontcover\&hl=hr\#v=onepage \& $q \& f=f a l s e(4.6 .2020)$

5. Biografija (2017). Biografije javnih osoba iz Hrvatske. Retrieved from: https://www.biografija. com/stjepan-hauser/ (3.12.2020)

6. Blaire Dawson, M. (2020). In PR, "Stunt" Should Not Be a Dirty Word. Retrieved from: https:// www.prweek.com/article/1697289/pr-stunt-not-dirty-word

7. Britannica (2020). Art. Retrieved from: https://www.britannica.com/art/visual-arts (2.12.2020)

8. CBG (2020). Split-Second 'Phantom' Images Can Fool Tes/a's Autopilot. Retrieved from: https:// cyber.bgu.ac.il (3.12.2020)

9. Chappuis, B. (n.d.). 5 Proven Methods for Driving Sales Excellence in Your Organization. Retrieved from: https://www.salesforce.com/quotable/articles/sales-excellence-methods/ (30.10.2020)

10. Clayton Hotel (2020). 10 Facts About the Boat Race. Retrieved from: https://www.claytonhotelcambridge.com/blog/10-facts-about-the-boat-race/ (1.12.2020)

11. Collins, N. (2008a). Conceptual Art - Meaning, Origins, Characteristics of Conceptualism. Retrieved from: http://www.visual-arts-cork.com/conceptual-art.htm (7.11.2020)

12. Collins, N. (2008b). Definition of Art - Meaning, Classification of Visual and Fine Arts, Aesthetics. Retrieved from: http://www.visual-arts-cork.com/art-definition.htm\#classification (7.11.2020)

13. Dale, S. B., Krueger, A.B. (1999). Estimating the Payoff to Attending a More Selective College: An Application of Selection on Observables and Unobservables. Quarterly Journal of Economics, 107(4), 1491-1527. Retrieved from: https://www.nber.org/papers/w7322 (4.6.2020)

14. Dubrovnik Summer Festival (2013). 64 $4^{\text {th }}$ Dubrovnik Summer Festival / 64. Dubrovačke ljetne igre - "Ispod mjeseca/Under the Moon". Retrieved from: https://youtu.be/PNdFHeYccR4 (3.12.2020)

15. Eide, E., Showalter, M. H. (1998). The Effect of School Quality on Student Performance: A Quantile Regression Approach. Economic Letters, 58(3), 345-350. Retrieved from: https://www.sciencedirect.com/science/article/pii/S0165176597002863 (4.6.2020)

16. Erstebank (n.d.). Erste fragmenti 16 - Mladi umjetnici znaju kako krizu pretvoriti u priliku. Retrieved from: https://www.erstebank.hr/hr/o-nama/drustveno-odgovorno-poslovanje/ erste-fragmenti\# (2.12.2020)

17. Fill, C. (2010). Marketing Communications, Interactivity, Communities and Content, ( $5^{\text {th }}$ Ed.) Prentice Hall

18. Flash Mob Geek (2019). Flash Mob - Sing Somebody to Love at University Cafeteria (HD). Retrieved from: https://www.youtube.com/watch?v=RSgRApOXd9Q\&ab_channel=FlashMobGeek (25.11.2020) 
19. Geoffrey, J. (2018). 7 Colleges Better Than Harvard - If You Want a Job After Graduation and One of Them Costs \$160,200 Less. Inc. Retrieved from: https://www.inc.com/geoffrey-james/7colleges-better-than-harvard-if-you-want-a-job-after-graduation.html (4.6.2020)

20. Graham, P. (2005). The Submarine. Retrieved from: http://www.paulgraham.com/submarine. html (19.8.2020)

21. Guja, N. (2019). Stjepan Hauser: "Sve ide k tome da postanem najveća zvijezda na svijetu". Retrieved from: https://story.hr/Celebrity/a122026/Stjepan-Hauser-Sve-ide-k-tome-da-postanem-najveca-zvijezda-na-svijetu.html (3.12.2020)

22. Hornblower, S., Spawforth, A. (2014). The Oxford Companion to Classical Civilization (2 ${ }^{\text {nd }}$ Ed.), Oxford University Press, UK

23. Horton, J., L. (2016). Publicity Stunts What Are They? Why Do Them? Retrieved from: https:// web.archive.org/web/20160304035325/http://www.online-pr.com/Holding/PRStuntsarticle. pdf (5.6.2020)

24. IRT (2019). Studenti Mašinskog fakulteta u Beogradu uspješno izveli prvi probni let svoje letjelice - Raven TL18. Retrieved from: https://irt3000.si/hr/vijesti/2019102110171924/Studenti-Mašinskog-fakulteta-u-Beogradu-uspješno-izveli-prvi-probni-let-svoje-letjelice---Raven-TL18/ (3.12.2020)

25. Koldyshev, M. (2020). Target-Audience Segmentation: Why You Need It and How to Do It in Five Easy Steps. Retrieved from: https://www.marketingprofs.com/articles/2020/43653/targetaudience-segmentation-why-you-need-it-and-how-to-do-it-in-five-easy-steps (30.10.2020)

26. Kučić, I. Š. (2017). Wings for Life: Riječki studentski tim najveći u povijesti. Retrieved from: https://www.novilist.hr/rijeka-regija/rijeka/wings-for-life-rijecki-studentski-tim-najveci-upovijesti/?meta_refresh=true (26.11.2020)

27. Kurelac, F. (2020). Studenti izveli opasnu manipulaciju autopilota Tesle - Projekcijom osoba, znakova i traka iz jeftinog drona zbunili skupi sustav što može biti fatalno! Retrieved from: https:// www.jutarnji.hr/autoklub/garaza/studenti-izveli-opasnu-manipulaciju-autopilota-tesle-projekcijom-osoba-znakova-i-traka-iz-jeftinog-drona-zbunili-skupi-sustav-sto-moze-biti-fatalno-9935017 (3.12.2020)

28. Leigh, R. (2017). My Slides from PR Fest 2017: "PR Stunts - a Relic of a Bygone Age, or a Useful $P R$ Tactic?" Retrieved from: https://www.radioactivepr.com/pr-fest-2017-a-pr-agency-look-atpr-stunts/ (17.3.2021)

29. Maringe, F., Gibbs, P. (2008). Marketing Higher Education - Theory and Practice, UK: Open University Press

30. Maryville University (n.d.). Careers in Corporate Connection: Strategic Communication vs. Public Relations. Retrieved from: https://online.maryville.edu/vs/strategic-communicationvs-public-relations/ (13.8.2020)

31. Media Update (2019). Three Reasons Why PR Is a Cost-Effective Option. Retrieved from: https:// www.mediaupdate.co.za/publicity/147258/three-reasons-why-pr-is-a-cost-effective-option (28.10.2020)

32. Muzička akademija u Zagrebu (n.d.). O Muzičkoj akademiji. Retrieved from: http://www.muza. unizg.hr/o-muzickoj-akademiji/ (3.12.2020)

33. Noble, W. (2020). The Oxford Vs Cambridge Boat Races 2020: How, Where and When to Watch Them. Retrieved from: https://londonist.com/london/sport/boat-race-oxford-cambridgewhen-where-how-watch (27.11.2020)

34. Online Etymology Dictionary (n. d.). Experiment (n.). Retrieved from: https://www.etymonline. com/word/experiment (3.12.2020) 
35. Parker, T. (2019). The Value of An Ivy League Education. Investopedia. Retrieved from: https:// www.investopedia.com/financial-edge/0811/the-value-of-an-ivy-league-education.aspx

36. Paun, M. (2013). Studenti izveli performans na temu glagoljice. Retrieved from: http://www. hrv.hr/vijesti/kultura/item/3963-studenti-izveli-performans-na-temu-glagoljice (3.12.2020)

37. Pickton, D., \& Broderick, A. (2001). Integrated Marketing Communications. Harlow: Pearson Education Ltd.

38. PRMR Inc. Public Relations Consultants (n.d.). How Important is Community Relations to a Company. Retrieved from: https://www.prmrinc.net/blog/how-important-is-community-relations-to-a-company (19.8.2020)

39. Reference for Business (n.d.). Public Relations. Retrieved from: https://www.referenceforbusiness.com/small/Op-Qu/Public-Relations.html (27.10.2020)

40. Semenik, R. J. (2002). Promotion \& Integrated Marketing Communications. Ohio: South Western Tomson Learning

41. Shimp, T. A. (2003). Advertising, Promotion \& Supplemental Aspects of Integrated Marketing Communications (6th ed.). Ohio: Tomson South Western

42. Steyn, B. (2003). From Strategy to Corporate Communication Strategy: A Conceptualisation, Journal of Communication Management, Vol.8, 2, 168-183.

43. Sugget, P. (2019). 10 Advertising and PR Stunt Ideas to Get Your Brand Noticed. Retrieved from: https://www.thebalancecareers.com/advertising-pr-stunts-to-get-your-brand-noticed-4139850 (23.5.2020)

44. The Boat Race Company (n.d.). Retrieved from: https://www.theboatrace.org/contact (27.11.2020)

45. The Complete Guide to PR Stunts (n.d.). Retrieved from: https://www.5wpr.com/new/publicity-stunt/ (17.03.2021)

46. Tomše, D., Snoj, B. (2014). Marketing Communication on Social Networks - Solution in the Times of Crisis. Marketing, 45(2), p. 131-138

47. Tportal (2020). ALU PERSPEKTIVA 2020 - završna godišnja izložba studenata Akademije likovnih umjetnosti u Zagrebu. Retrieved from: https://www.tportal.hr/kultura/clanak/aluperspektiva-2020-zavrsna-godisnja-izlozba-studenata-akademije-likovnih-umjetnosti-uzagrebu-20200916 (2.12.2020)

48. Tymowicz, J. (n.d.). Brand Image Building Process. Retrieved from: https://www.ideoforce. com/solutions/brand-image-building-process/ (29.10.2020)

49. U.S. and Canadian Institutions Listed by Fiscal Year (FY) 2018 Endowment Market Value and Change in Endowment Market Value from FY 2017 to FY 2018. (2018). National Association of College and University Business Officers and Commonfund Institute. Retrieved from: https:// www.nacubo.org/-/media/Nacubo/Documents/research/2018-Endowment-Market-Values-Final.pdf

50. Volarić, T. (2016). Studenti i učenici napisali su i izveli novu operu u Šibeniku! Retrieved from: https://www.24sata.hr/show/studenti-i-ucenici-napisali-su-i-izveli-novu-operu-u-sibeniku-503366 (3.12.2020)

51. Wilson, R., M., S., Gilligan, C. (2005). Strategic Marketing Management - Planning, Implementation \& Control, (3rd ed.) Elsevier Butterworth-Heinemann 